\title{
APLIKASI MOBILE LEARNING PADA MATA PELAJARAN SEJARAH KEBUDAYAAN ISLAM
}

\author{
Dedi Putra Widi Utama ${ }^{1}$, Rini Agustina ${ }^{2}$ \\ Sistem Informasi, Universitas Kanjuruhan Malang ${ }^{1,2}$ \\ Email bramasto1234@gmail.com ${ }^{1}$, riniagustina@ unikama.ac.id ${ }^{2}$
}

\begin{abstract}
Abstrak. Perkembangan media dalam pembelajaran dapat membentuk suatu rancangan untuk membuat aplikasi pembelajaran bagi siswa dan memudahkan siswa untuk membantu proses pembelajaran yang ada di sekolah. Konsep ini yang digunakan sekolah untuk meningkatkan potensi belajar bagi siswa dan meningkatkan pengetahuan siswa, dengan konsep pembelajaran jarah jauh yaitu siswa bisa belajar dimanapun dan kapanpun.Sebagai salah satu pendidikan sekolah menengah keatas MAN 1 Malang di kabupaten malang, merupakan salah satu madrasah aliyah negeri yang mengutamakan peserta didiknya untuk mendalami ilmu agama diantaranya yaitu mata pelajaran (SKI). Dari hasil penelitian yang dilakukan dapat membantu siswa dalam proses belajar dan pada hasil User Acceptence Test (UAT) dengan rata-rata $80,15 \%$.
\end{abstract}

Kata Kunci: Aplikasi Mobile Learning, Sejarah Kebudayaan Islam (SKI) di MAN 1 Malang.

\section{PENDAHULUAN}

Perkembangan media dalam pembelajaran dapat membentuk suatu rancangan untuk membuat aplikasi pembelajaran bagi siswa dan memudahkan siswa untuk membantu proses pembelajaran yang ada di sekolah.

Berdasarkan hasil obbservasi dan wawancara yang dilakukan dengan guru mata pelajaran Sejarah Kebudayaan Islam sebagai salah satu mata pelajaran yang ada di MAN 1 Malang, siswa yang menggunakan handphone android sudah sangat banyak contohnya dari kelas X bahasa yang di ajar oleh beliau . Hasil wawancara oleh siswa di MAN 1 Malang, kebanyakan siswa handphone hanya sebatas untuk mengakses media sosial seperti facebook, instagram dan MiChat bahkan untuk bermain game.

Dalam proses pembelajaran sejarah kebudayaan islam (SKI) masih menggunakan metode ceramah yang menurut siswa membosankan., Siswa hanya mencatat materi dan mendengarkan materi yang gurunya sampaikan. Berdasarkan permasalahan tersebut, dapat mempengaruhi potensi belajar siswa khususnya Sejarah Kebudayaan Islam (SKI).

Menurut guru mata pelajaran SKI hasil belajar siswa pada saat siswa diberi tugas pekerjaan rumah (PR) masih bervariasi, tidak semua hasil belajar siswa-siswi itu tinggi dan rendah. Nilai KKM yang di tentukan oleh sekolah yaitu 75 dan masih terdapat beberapa hasil belajar siswa yang kurang memuaskan atau dibawah KKM (Kriteria Ketuntasan Minimal) yaitu 65\% dari murid kelas X bahasa MAN 1 Malang.

Berdasarkan permasalahan di atas, saya ingin membuat sebuah aplikasi yang mempermudah para siswa-siswi MAN 1 Malang untuk belajar melalui handphone android yang mereka miliki khususnya pada pelajaran Sejarah Kebudayaan Islam (SKI).

\section{METODE PENELITIAN}

\subsection{Metode Waterfall}

Metode waterfall ini mempunyai alur seperti air terjun, memiliki tingkatan-tingkatan seperti Communication, Planning, Modelling, Contruction dan Deployment di setiap alur memiliki tugas masing-masing menurut.(Pressman, 2015) 


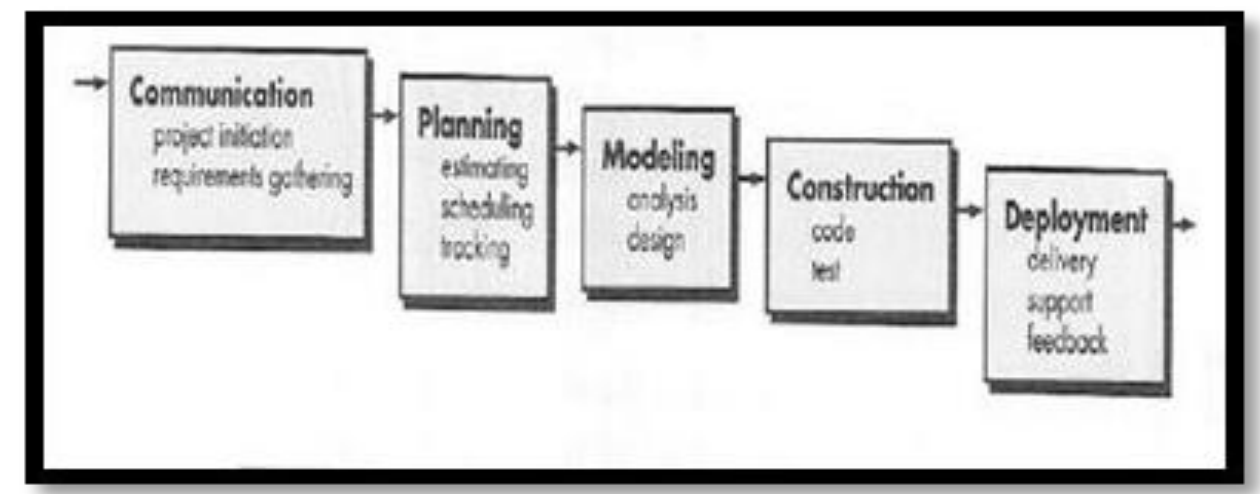

\section{Gambar Ilustrasi Model Waterfall}

\subsection{Communication}

Penelitian ini melakukan observasi dan wawancara kepada pihak sekolah yaitu guru dan siswa di MAN 1 Malang dengan tujuan untuk mengetahui permasalahan dan kebutuhan yang akan digunakan.

\subsection{Planning}

Tahap planning adalah perancangan alur kegiatan yang akan di lakukan untuk penelitian aplikasi mobile learning yang akan dilaksanakan di MAN 1 Malang.

Tabel Data Planning Kegiatan

\begin{tabular}{clrl}
\hline NO & \multicolumn{2}{c}{ Jenis kegiatan } & \\
\hline 1 & $\begin{array}{l}\text { Memberikan surat } \\
\text { izin penelitian } \\
\text { MAN 1 Malang }\end{array}$ & ke & $\begin{array}{l}\text { Sebelum melakukan wawancara kepada pihak sekolah terlebih } \\
\text { dahulu penulis memberikan surat izin penelitian dengan jangka } \\
\text { waktu 2 minggu }\end{array}$ \\
\hline 2 & $\begin{array}{l}\text { Observasi dan } \\
\text { wawancara mengenai } \\
\text { sistem }\end{array}$ & $\begin{array}{l}\text { Dalam kegiatan ini dimaksudkan untuk lebih mencari } \\
\text { permasalahan dalam sekolah tersebut dengan jangka waktu 3 } \\
\text { minggu }\end{array}$ \\
\hline 3 & $\begin{array}{l}\text { Membahas } \\
\text { kesepakatan sistem }\end{array}$ & $\begin{array}{l}\text { Setelah melakukan observasi dan wawancara selanjutnya penulis } \\
\text { mencoba membuat alur sistem yang nantinya akan di rancang } \\
\text { dengan jangka waktu 1 minggu }\end{array}$ \\
\hline 4 & Pembuatan sistem & $\begin{array}{l}\text { Setelah disepakati akan sistem yang akan di bangun langkah } \\
\text { selanjutnya adalah penulis akan melakukan perancangan databse } \\
\text { hingga pengkodean dengan jangka waktu 7 minggu }\end{array}$ \\
& & $\begin{array}{l}\text { Setelah melakukan serangkaian pembuatan sistem selanjutnya } \\
\text { penulis akan menguji cobakan sistem kepada guru dan siswa } \\
\text { MAN 1 Malang }\end{array}$ \\
\hline 5 & Implementasi dan uji \\
& coba &
\end{tabular}

\subsection{Modelling (Analysis dan Design)}

\section{a. Desain Perancangan Sistem}

UML (Unified Modeling Language) adalah untuk merancang sebuah aplikasi yang nanti kita butuhkan untuk pembuatan aplikasi. UML (Unified Modeling Language) merupakan bagian dari Use Case Diagram, Activity Diagram, Squence Diagram dan Class Diagram

\section{b. Use Case Diagram Utama}

Use case diagram digunakan untuk menjelaskan alur utama program seperti menggambarkan alur sistem yang akan dikerjakan oleh aktor-aktor yang terdapat dalam aplikasi mobile learnning contoh ada dibawah ini: 


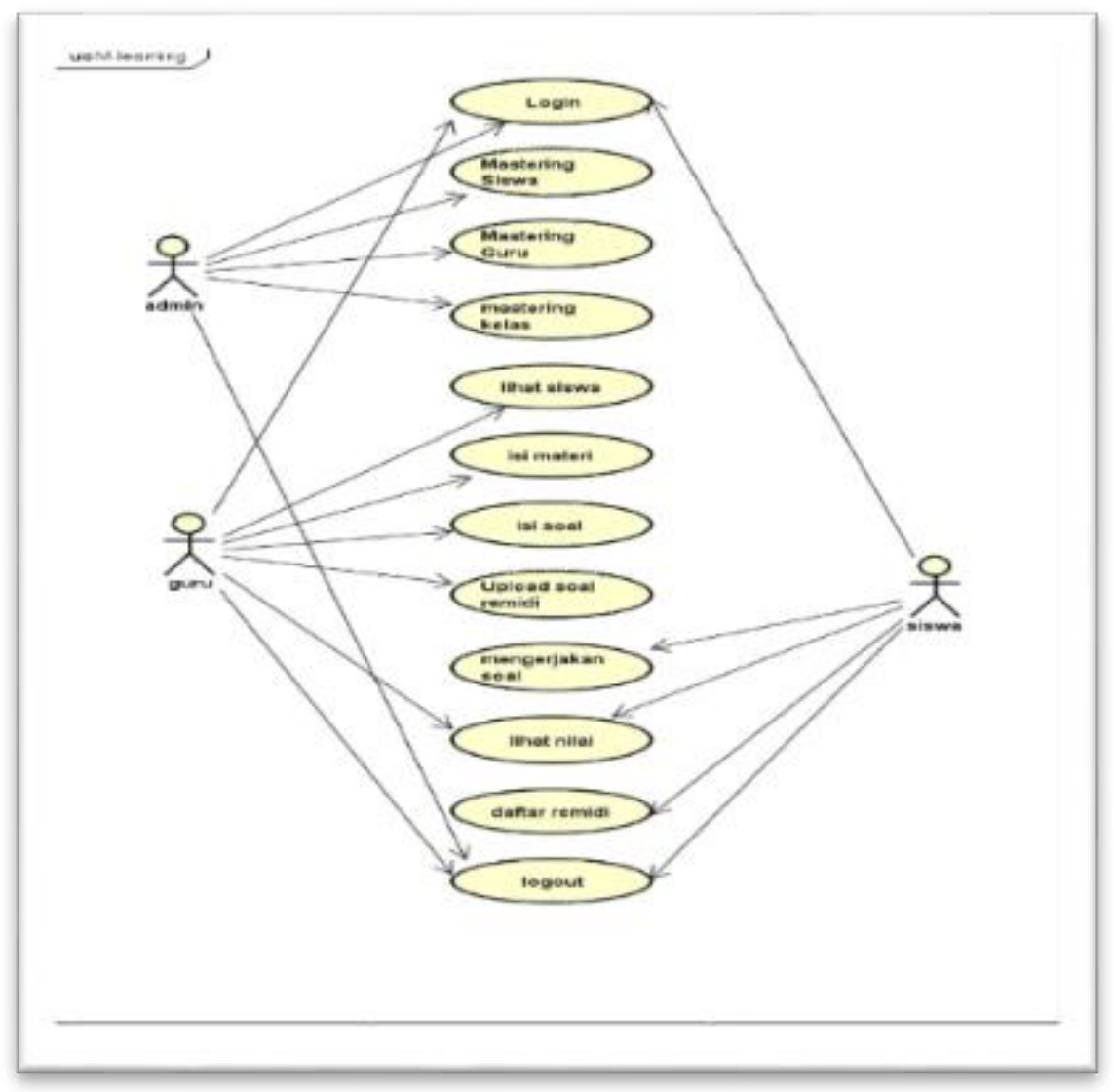

Gambar Use Case Diagram Utama

\section{c. Class Diagram}

pkgpembelajaran

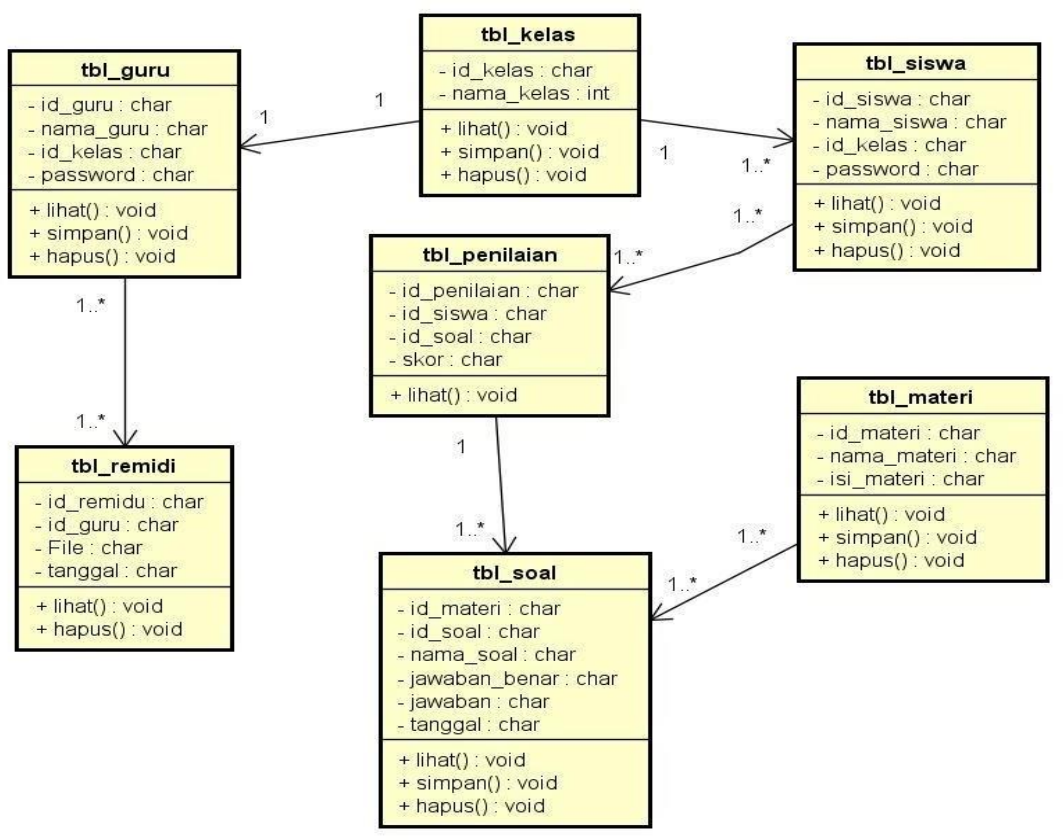




\subsection{Contruction (code dan test)}

Contruction adalah sebuah tahapan dimana proses dari sebuah logika penggambaran program ke bahasa mesin supaya dapat di mengerti oleh mesin dan menjalankan program itu sendiri.

\subsection{Deployment}

Aplikasi mobile learning Sejarah Kebudayaan Islam (SKI) di man 1 malang terdapat tiga aktor yaitu admin, guru dan siswa. Di mana tugas admin sebagai pengelolah data mastering di dalam aplikasi. Guru bertugas sebagai pengelolah data materi dan soal sedangkan siswa sebagai aktor yang bertugas melihat materi dan video sekaligus pengerjaan soalnya.

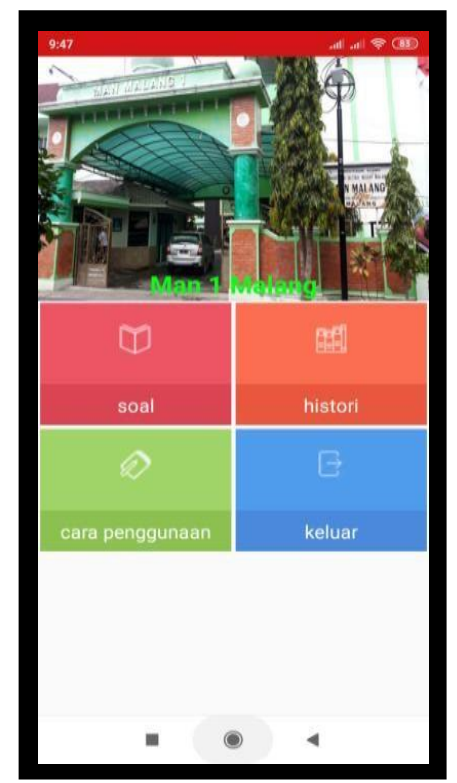

Gambar Home

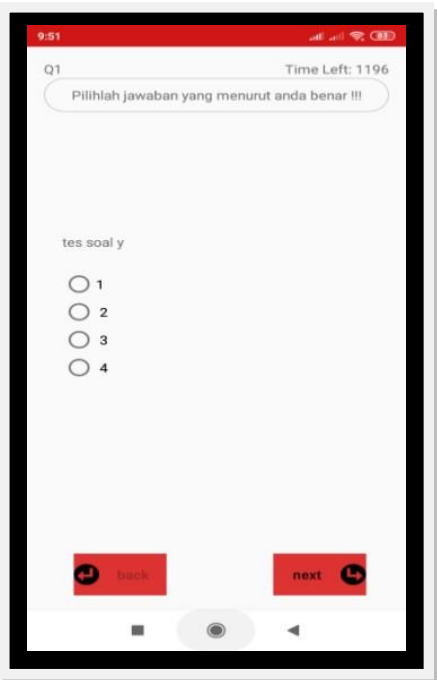

Gambar Halaman Soal 


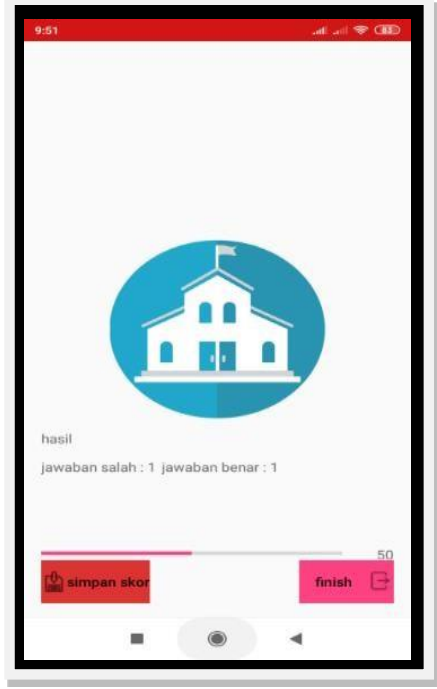

\section{Gambar Halaman Skor}

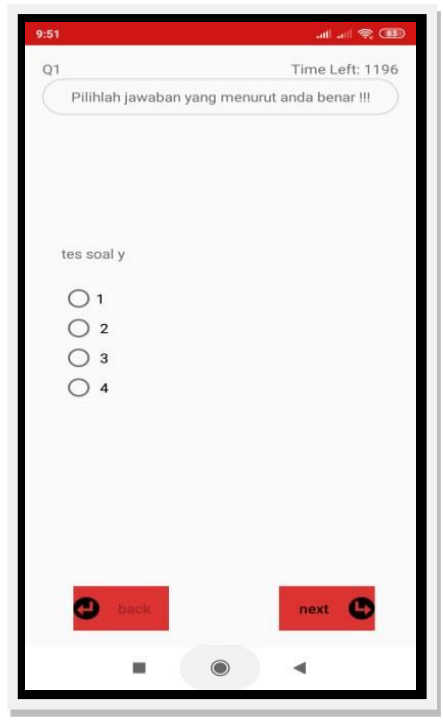

\section{Gambar Halaman Quiz}

\subsection{Pembahasan UAT}

Dalam proses penelitian UAT disebarkan kepada siswa-siswi kelas X Bahasa MAN 1 Malang dengan total responden adalah 30 orang. Setelah melakukan penyebaran UAT dan mendapatkan jawaban dari responden, langkah selanjutnya melakukan perhitungan pada hasil jawaban dan menentukan presentase tiap pemilihan jawaban. Hasil analisa bisa di lihat di bawah ini :

Tabel Hasil Analisa

\begin{tabular}{|c|c|c|c|c|}
\hline Pertanyaan & Jml & $\begin{array}{c}\text { Nilai } \\
\text { Jml/Res }\end{array}$ & $\%$ & AVG \\
\hline \multicolumn{5}{|c|}{ ASPEK SISTEM (SYSTEM } \\
\hline 1 & 130 & 4,3 & $86 \%$ & \multirow{4}{*}{$\mathbf{8 1 , 3 5 \%}$} \\
\hline 2 & 122 & 4,07 & $81,4 \%$ & \\
\hline 3 & 120 & 4 & $80 \%$ & \\
\hline 4 & 117 & 3,9 & $78 \%$ & \\
\hline \multicolumn{5}{|c|}{ ASPEK PENGGUNA (USER) } \\
\hline 5 & 126 & 4,2 & $84 \%$ & \multirow{2}{*}{$78,7 \%$} \\
\hline 6 & 117 & 3,9 & $78 \%$ & \\
\hline
\end{tabular}




\begin{tabular}{|c|c|c|c|c|}
\hline 7 & 110 & 3,7 & $74 \%$ & \\
\hline \multicolumn{5}{|c|}{ ASPEK INTERAKSI (INTERACTION) } \\
\hline 8 & 121 & 4,03 & $80,6 \%$ & \\
\hline 9 & 123 & 4,1 & $82 \%$ & $80,4 \%$ \\
\hline 10 & 118 & 3,93 & $78,6 \%$ & \\
\hline RATA-RATA TOTAL \% & & & & $80,15 \%$ \\
\hline
\end{tabular}

\section{HASIL DAN PEMBAHASAN KESIMPULAN}

Berdasarkan hasil pembuatan Aplikasi mobile learning berbasis android pada mata pelajaran ski di MAN 1 Malang yang telah dilakukan uji coba terhadap sistem yang telah dibuat, dengan melakukan pembagian kuisoner kepada 30 siswa di MAN 1 Malang, dengan hasil perhitungan (UAT) di dapatkan nilai rata-rata yaitu $80,15 \%$ maka dapat ditarik kesimpulan bahwa sistem yang dibuat dapat mempermudah siswa dan guru di MAN 1 Malang dalam mengerjakan soal dan menyampaikan materi dari mata pelajaran (SKI). Aplikasi mobile learning berbasis android pada mata pelajaran SKI di MAN 1 Malang di nyatakan setuju atau bermanfaat bagi siswa dalam melakukan proses menjawab soal dan membaca materi dari mata pelajaran (SKI).

\section{SARAN}

Pada penelitian pengembangan ini masih terdapat kekurangan yang masih belum tercapai semoga bisa dikembangkan lagi oleh peneliti selanjutnya :

1. menambahkan akor wali murid untuk memonitoring hasil nilai dari pengerjaan soal ski.

2. menambahakan fitur download materi tambahan jika siswa saat menegrjakan soal ski tidak mendaptkan nilai tinggi meskipun telah mengerjakan berulang kali.

\section{Daftar Pustaka}

Arif, Muhammad Budi. 2016. "Model Pembelajaran ICT Literacy M-Learning Untuk Meningkatkan Hasil Belajar Mata Pelajaran Pendidikan Agama Islam Di MTs. Brawijaya Mojokerto.

Gautama, Idris and Fajar Kurniawan. 2015. "Perancangan E-Learning Berbasis Internet Pada Sekolah Smk Negeri 13 Jakarta.” 1(2):394-406.

Pressman. 2015. "Software Engineering A Practitiooner's Approach."

Tsvetozar, et al. 2011. "Sebagai Strategi Pembelajaran Bahasa Telah Banyak Dilakukan.

Beberapa Penelitian Yang Telah Dikakukan, Antara Lain Seperti Yang Dilaksanakan Oleh Salameh Osama Yang Merancang Sebuah Sistem." 8-20.

Handayani, Ardian.2017. "Pengembangan Media Pembelajaran Mobile Learning Dengan Menggunakan Aplikasi Android Pada Mata Pelajaran Teknik Listrik Di Smk Negeri 1 Jetis Mojokerto.

Hikam, M. 2018. Analisis dan Pengembangan Sistem Informasi Penilaian Kinerja Guru Berbasis WEB di SMK Negeri 2 Yogyakarta. Skripsi. Yogyakarta. Universitas Negeri Yogyakarta.

Jogiyanto. 2005. Analisis Dan Desain Sistem Informasi. jogiyanto. yogyakarta: Andi.

Matlubah, Helliyatul. 2016. "Aplikasi Mobile Learning Berbasis Smartphone Android Sebagai Sumber Belajar Mahasiswa Program Studi Pendidikan IPA Universitas Wirajaya 
Sumenep." 6(November):

Peraturan Menteri Pendidikan Nasional Republik Indonesia Nomor 12 Tahun 2007 tentang Standar Pengawas Skolah/Madrasah. Direktorat Jenderal Pendidikan Dasar dan Menengah Kementrian Pendidikan dan Kebudayaan. (Online), (http://dikdasmen.kemdikbud.go.id/), diakses 28 Oktober 2019 